\title{
15 Years of Civil Service Reform in Romania
}

\author{
Dragos Dinca* \\ National School of Political Science and Public Administration, Bucharest, Romania
}

Submission: April 29, 2021; Published: May 19, 2021

"Corresponding author: Dragos Dinca, National School of Political Science and Public Administration, Povernei St., no. 6-8, Bucharest, Romania

Abstract

Ever since 1999, when the Law 188 on the Civil Servants' Statute was passed, this staff category in the Romanian public administration has been subjected to ongoing reform attempts. There hasn't been any government program that has not devoted whole chapters to the civil service reform. Reform strategies have been developed, normative acts have been adopted and amended in an attempt to increase the performance of public institutions by raising the professional training level of civil servants.

This article aims to conduct an inventory of the civil service reform initiatives from 2005-2020 (government programs, reform strategies), to review the extent to which these initiatives have been put into practice, and especially to carry out a comparative analysis on the civil servants perception of the reform measures using the same type of data collected in 2005 and 2020.

The underlying assumption of this article is that important steps have been taken to reform the civil service, but the outcomes thereof have been limited. The research objective is to assess the status of the public service reform and to make proposals for the continuation of the reform process.

Keywords: Civil Service; Reform; Public administration; Law; Political servants; Human resource management

\section{Staff Categories in Romanian public administration}

Public administration is a system of organizations, intertwined by a multitude of relations of collaboration, subordination, participation, services provision, etc., made into a real network that provides both the framework required for the enforcement of the law and for its accurate implementation, a system ensuring the continuity and permanence of the state and local communities. Considering the full scope, the variety of the public administration organizations network and the complexity of activities to be carried out within, as well as the fact that public administration itself is nothing other than people carrying out tasks in relation to other people, one can conclude that public administration performance can only be achieved with capable, competent, active, well trained people who understand the concept of public service.

The effectiveness and efficiency of public administration organizations in carrying through their tasks depends largely on the human quality and professional capacity of those working within. In other words, the value and potential of these organizations are significantly linked to the quality of the people they employ.
The human quality of civil servants, their professional training and their will to carry out their duties are key to social order and even to general well-being. There are about 173,000 civil service positions in the Romanian public institutions (56\% at local level, $44 \%$ at state level), 135000 positions are filled ${ }^{1}$, with a ratio of $68 \%$ being occupied by women and $32 \%$ by men. Apart from civil servants, Romanian public administration also employs contractbased staff and "political servants". Schematically, a taxonomy of public administration staff would include:

\section{i. Civil servants}

- High civil servants $(0,16 \%$ from the overall number of civil servant positions);

- Civil servants holding management positions $(11,2 \%$ from the overall number of civil servant positions);

- Civil servants holding executive positions $(88,64 \%$ from the overall number of civil servant positions)

\footnotetext{
${ }^{1}$ Activity Report of the National Agency of Civil Servants for 2018, p.12

http://www.anfp.gov.ro/R/Doc/2019/rapoarte\%202019/Raport\%20de\%20activitate\%20ANFP\%202018.pdf
} 


\section{ii. Contract based staff}

\section{iii. Political servants}

\section{Civil service reform initiatives}

All government programs from 2005-2020 included provisions on the civil service reform.

The Government Program 2005 - 2008² included a chapter on the management of human resources in the public administration. Elements such as: recruitment, career, classification, performance indicators, training, salary, discipline rules, the de-monopolization of the system of training and professional development in public administration $^{3}$ are considered, alongside other proposals such as: the implementation of the ethics code for civil servants and its enforcement throughout the entire system of public administration; the training of civil servants in Community law and in the implementation of European programs ${ }^{4}[1]$; ensuring transparency of competition rules and of civil servants recruitment and selection procedures.

The Government Program 2009 - $2012^{5}$ included in the chapter on public administration, provisions on the reform of human resources management in public administration and contained three measures: implementation of the provisions of the Framework Law on the unitary remuneration of staff paid from public funds; review of the procedures for assessing the performance of public administration staff; continuous training of central and local public administration staff to increase professional performance.

The Government Program 2013 - $2016^{6}$ aimed to promote policies to increase the professional performance of public administration staff by decentralizing the management of civil service onto the credit officers/heads of institutions (i.e. recruitment, promotion, civil service fixed-term posting) aiming to simplify and streamline the administrative system and also revise the system of professional performance evaluation.

The Government Program 2017 - $2020^{7}$ chapter on public administration and regional policies includes the lines of action and approaches to be taken targeting the civil service. The actions aim primarily at reducing the role of the National Civil Servants' Agency in organizing and endorsing competitions for filling in civil servant positions. The measures mainly concern the management of the number of positions, as well as a legislative clarification of the rules applicable to certain categories of staff required from the perspective of the many changes in regulations and the statute.

In one form or another, the government programs mentioned focused on similar approaches on the civil service: recruitment and selection, performance evaluation, payroll, education and training, ethical behavior. For 15 years, different governments and their programs have treated the issue of the civil service largely in the same way.

The Strategy for Strengthening Public Administration 2014 - $2020^{8}$ (SSPA) is the most consistent document on the reform of human resources in general and the civil service in particular. It was approved by the Government Decision no. 909/2014, aiming for Romania to have an efficient and responsive public administration by 2020 [2].

The $3^{\text {rd }}$ pillar in the Strategy for Strengthening Public Administration 2014-2020 [3], namely Human Resources is focused on the goal of "Implementing a performance management in public administration", structured on 3 specific objectives: Adapting the human resources policies and systems to the goals and requirements of a modern administration; Promoting ethics and integrity in public administration and pursuing measures to reduce and prevent corruption while ensuring support for the implementation of relevant recommendations made under the Cooperation and Verification Mechanism (MCC) and the Quality, Research and Innovation in Public Administration initiative.

Within the specific objectives mentioned, there are 7 measures, 30 sub-measures, 80 expected outcomes, each of these measures being broken down in actions, estimated budgets, and people assigned to the tasks and implementation deadlines set.

The Strategy for the development of the civil service 2016 - $2020^{9}$ [4], derived from the Strategy for Strengthening Public Administration 2014 - 2020, proposes a series of actions aimed at clarifying the role and assignment of the National Civil Servants Agency and strengthening its administrative capacity for it to provide a quality management of the civil service in line with the needs of the administration, the setup of a "board" like governance, in the form of an independent structure issuing public policies and legislative proposals for the regulation of the civil service and human resources in the public administration, the clarification of roles/assignments of different categories of human resources working in public administration.

\footnotetext{
${ }^{2}$ Government Program 2005 - 2008, published in the Official Journal no. 1265 on December 29, 2004

${ }^{3}$ Abolition of the monopoly of the National Institute of Administration set up in the year 2001

${ }^{4}$ The action aimed to prepare civil servants for the 2007 - accession of Romania to the EU

${ }^{5}$ Government Program 2009 - 2012, Published in the Official Journal no. 907 on 23 December 2009

${ }^{6}$ Government Program 2013 - 2016, posted on the website of the Government of Romania, available at: http://gov.ro/fisiere/pagini_fisiere/13-08-02-10-4852program-de-guvernare-2013-20161.pdf

${ }^{7}$ Government Program 2017 - 2020, posted on the website of the Government of Romania, available at http://gov.ro/fisiere/pagini_fisiere/PROGRAMUL_DE_ GUVERNARE_2018-2020.pdf

${ }^{8}$ Strategy for Strengthening Public Administration (SSPA) 2014 - 2020, posted on the website of the Ministry of Rural Development and Public Administration, available at:

http://www.dpfbl.mdrap.ro/documents/strategia_administratiei_publice/Strategia_pentru_consolidarea_administratiei_publice_2014-2020.pdf
} 
The Strategy on Professional Training in the Public Administration 2016 - 2020 $0^{10}$ [5] is meant to complement and support the institutional framework for the professionalization of public administration.

\section{Review of the implementation of the public service} reform initiatives

Among the above-mentioned initiatives, only the Strategy for Strengthening Public Administration 2014-2020 and the two strategies derived from it are accompanied by action plans, measures, deadlines, and people in charge and indicators, easing the evaluation of their progress achievement. The government programs mentioned are mere governmental statements of intention of the 7 measures under Pillar 3 - Human Resources, SSPA $^{11}$, none were fully implemented, 8 sub-measure are being implemented $(26.66 \%)$ and 22 are in progress $(73.33 \%)$. From the perspective of achieving the expected outcomes, 35\% were achieved in the $2014-2018$ period, with $12.5 \%$ being reached in 2020 and a high percentage of $52.5 \%$ to be achieved by the end of 2020 (Figure 1).

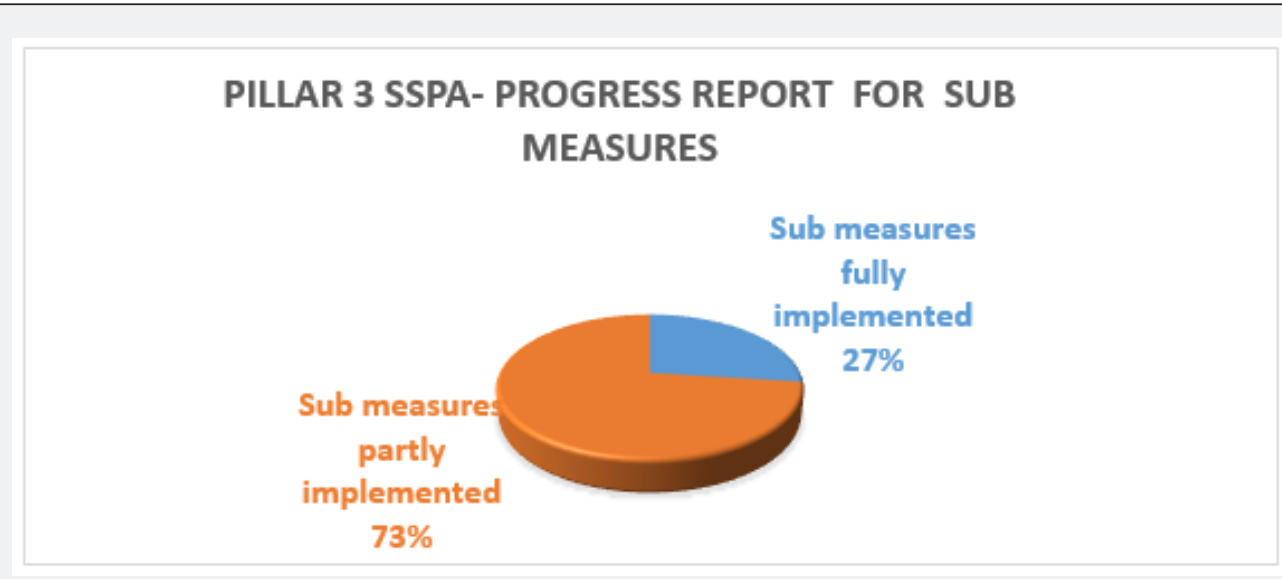

Figure 1: Progress report on sub measures included in Pillar 3, SSPA.

It's worth noting the progress made as well as the series of accomplishments on the reform of the civil service, from the period under review, which are however reduced in number in relation to the objectives set, but nonetheless important, namely:

i. Updates, targeted amendments of the Law no. 188/1999 on the Civil Servants' Statute, which clarified the civil servant career path and the management of civil service positions provided by the National Agency of Civil Servants [6];

ii. The setup of a professional performance assessment system through GD 611/2008, which provides that the appraisal of the individual performances is conducted exclusively by the one's hierarchical superior;

iii. The establishment of the National Council for the
Development of the Human Resources in Public Administration under Law 446/2018;

iv. The re-establishment of the National Institute of Administration $^{12}$ under Law no. 44/2017 approving the Government Ordinance no. 23/2016;

v. The revision of the salary system under the framework Law no.153 / 2017; The bill ensures decentralization of the decision making process regarding the remuneration in the local public administration;

vi. The issuance, implementation and monitoring of the National Anticorruption Strategy for 2012-2016 and 2016-2020;

vii. Reviews were conducted to substantiate some strategic decisions regarding the public service ${ }^{13}$.

\footnotetext{
${ }^{9}$ Strategy for the development of the civil service 2016 - 2020, published in The Official Journal no. 700 bis on 8 September 2016

${ }^{10}$ Strategy on Professional Training in the Public Administration 2016 - 2020, approved by Government Decision no. 620 of 2016 , published in the Official Journal no. 777 of 4 October 2016

${ }^{11}$ Impact Assessment Report of the measures implemented under the SCAP 2014-2020 on Pillar III - Human Resources, April 2019, coordinator Dragoş Dincă, within the project "Improving the capacity of CNCISCAP to coordinate the implementation of the Strategy for Strengthening the Public Administration 20142020”, Code: SIPOCA 24, Beneficiary: GENERAL SECRETARIAT OF THE GOVERNMENT

${ }^{12}$ The National Institute of Administration was dissolved in 2009

${ }^{13}$ Analysis of the current situation of staff recruitment and evaluation systems in terms of applying the rules in force; Analysis of competence frameworks / occupational standards according to identified strategic and specific areas; Analysis on strengthening the role of NACS and / or setting up an institution for the management of the contract-based staff in the public administration.
} 


\section{Annals of Social Sciences \& Management studies}

In recent years, civil service reform measures are substantially funded by the Operational Program for Administrative Capacity, a number of objectives being the subject of projects under implementation or evaluation ${ }^{15}$.

During this period, there were no substantiated approaches to review the overall recruitment and selection procedures and the performance evaluation system, by introducing new assessment tools. In terms of training, there were a number of measures that we consider incoherent/inconsistent (the dissolution and re-establishment of the National Institute of Administration). However, there did exist a unitary approach in terms of ethics and integrity. Perhaps the most important achievement for the period under review is the regulations on the unitary salary of staff.

The perception of Civil servants on public service reform - comparative analysis 2005-2020

Civil service reform has been a constant concern of the law- makers for the past 15 years. Various proposals were formulated, strategies elaborated, bills drafted and amended and the institutional system for the civil service management was revised.

Beyond these concerns, the views of civil servants, the direct beneficiaries of reform measures, may differ. Thus, we analyzed and presented these views comparatively, by carrying out two similar analyzes for the years 2005 and 2020.

While in 2005 civil servants considered that the reform processes at that time encouraged the development and capitalization of the potential (Figures 2 \&3), nowadays they would rather believe that the main theme the reform processes encouraged was to attract young people, in a much lower percentage than in 2005. However, Overall, all reform themes proposed are deemed to be regressing, which shows a decrease in the overall confidence in the success of the public service reform processes.

\section{The current civil service reform process encourages (2020):}

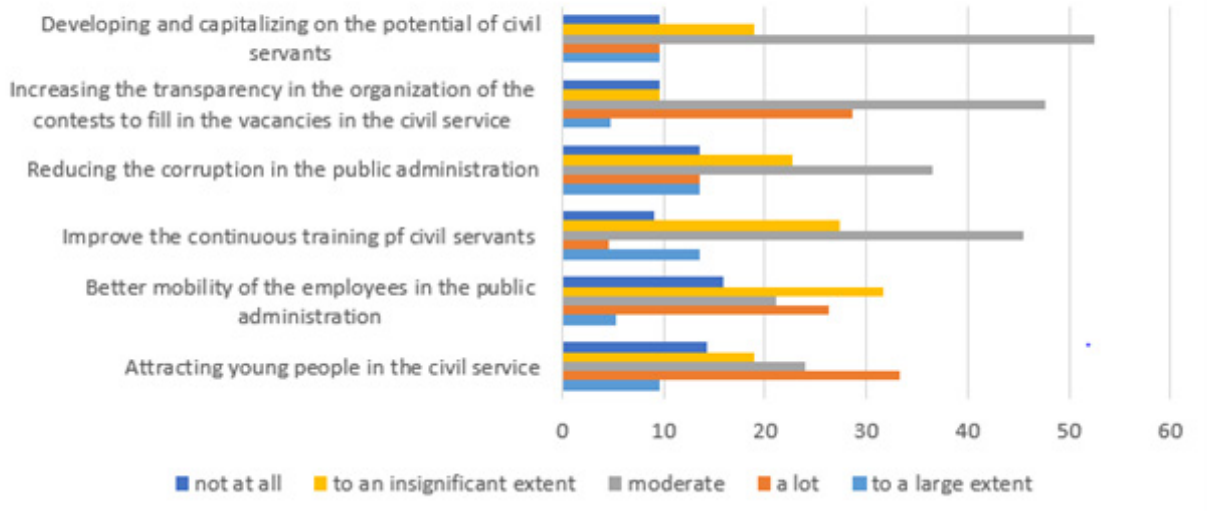

Figure 2: Themes encouraged by the current civil service reform (2020).

Most reform initiatives in recent years have focused on the recruitment and selection processes, the increase in transparency of the selection process, ensuring the objectivity of the candidates' assessment and their skills. Specific measures in this regard are proposed by the Strategy for the Development of the Civil Service for 2016 - 2020, but which have not been yet operationalized/put into practice.
The percentage of civil servants who consider that the civil servants selection process encourages /focuses (Figure 4) on the memorization of facts, ideas or methodologies from manuals or regulations in order to reproduce them in the same form, has increased in 2020 compared to 2005. This method of holding the competitions/contests is irrelevant, it does not include methods, skills assessment tools, practical tests or case studies.

${ }^{14}$ Project SIPOCA 63 - Ethics: Efficiency, Transparency and Interest in Conduct for Administration - Applicant: NACS;

Project SIPOCA 61- Strengthening integrity systems - the best strategy to prevent corruption in public administration, Applicat: MRDPA;

Project SIPOCA 136 - Developing a unitary management system of human resources in public administration, Applicant: GSG, Partners: NACS and MLSJ

${ }^{15}$ Both in 2005 and in 2020, 120 questionnaires were applied, sampling taking into account administrative levels (central, territorial, local), gender of respondents (men / women), level of education. 
The current civil service reform process encourages (2005):

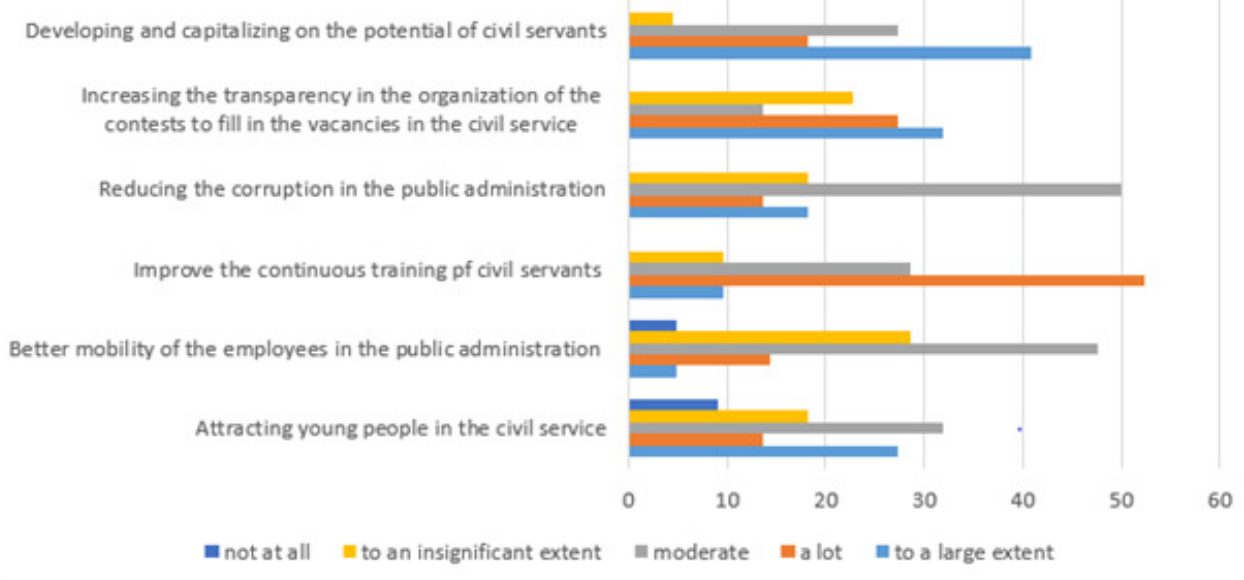

Figure 3: Themes encouraged by the current civil service reform (2005).

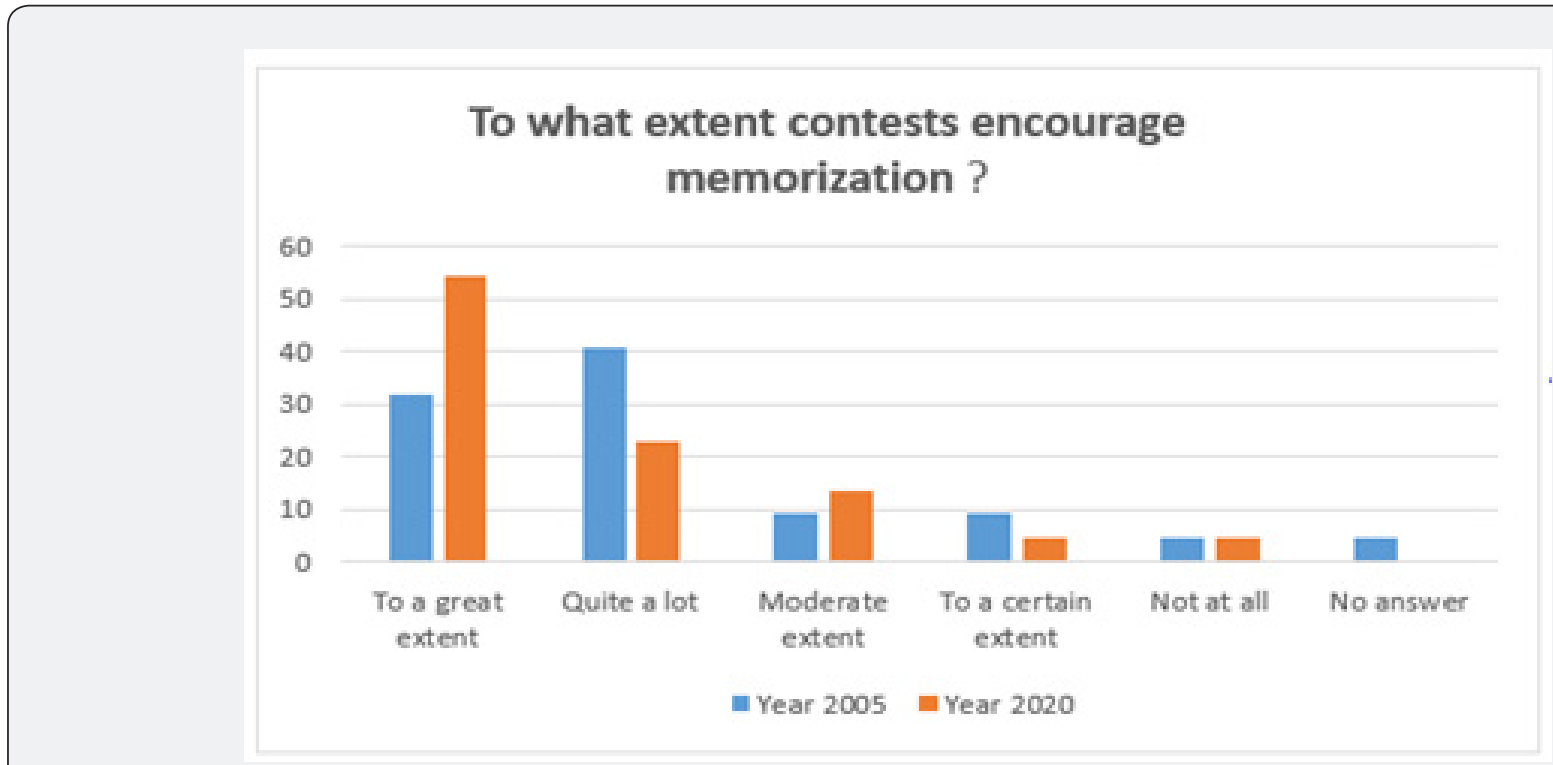

Figure 4: The extent to which contests encourage memorization.

From the perspective of motivation factors, in 2020 we can see the results of the adoption of the law on unitary pay, the pay (Figure 5) being considered the main motivation factor, followed by the satisfaction of doing useful things for the community (a common element from the evaluation of 2005 (Figure 6).

We can find that in 2020 most of the motivational factors listed are on the increase, indicating improvements in terms of management style, working conditions or professional recognition.
The attendance rate of long-term and short term training programs has dropped significantly in 2020 (Figure 7), as it can be noticed in Figure 2 as well. While up to 2009 there was a constant concern of public institutions for the training of employees, after the dissolution of the National Institute of Administration, during 2010-2016, little financial resources were allocated to the field of civil servants training. During this period, the training was under the responsibility of the National Agency of Civil Servants, which, on account of its reduced administrative capacity for such 
activities, has set up a partnership system with NGOs, universities, business companies (similar to a franchise). In 2016, the National Institute of Administration was re-established and has become partially operational in 2018. It positioned itself on the training market as a simple service provider in competition with the other private providers of training services.

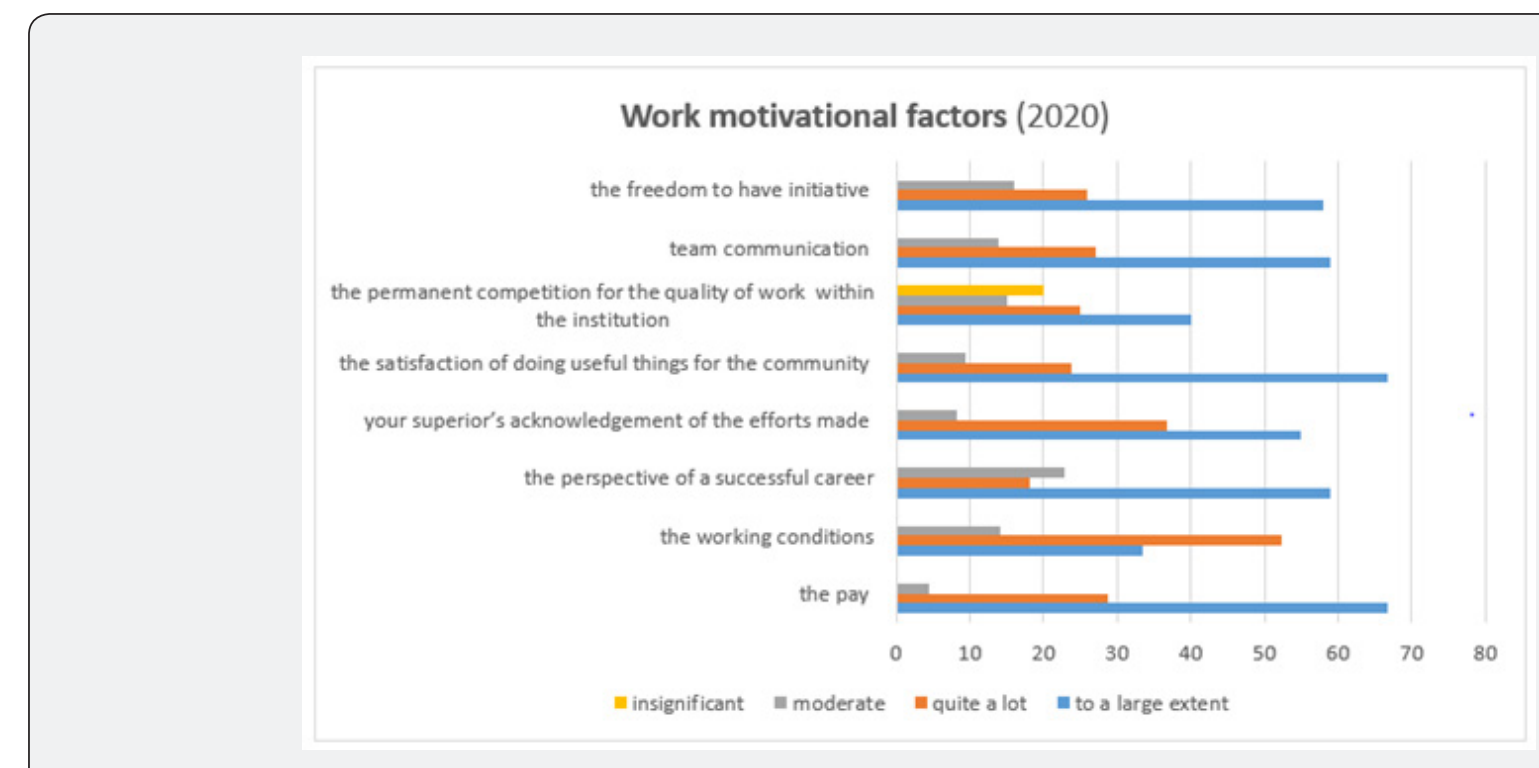

Figure 5: Work motivational factors (2020).

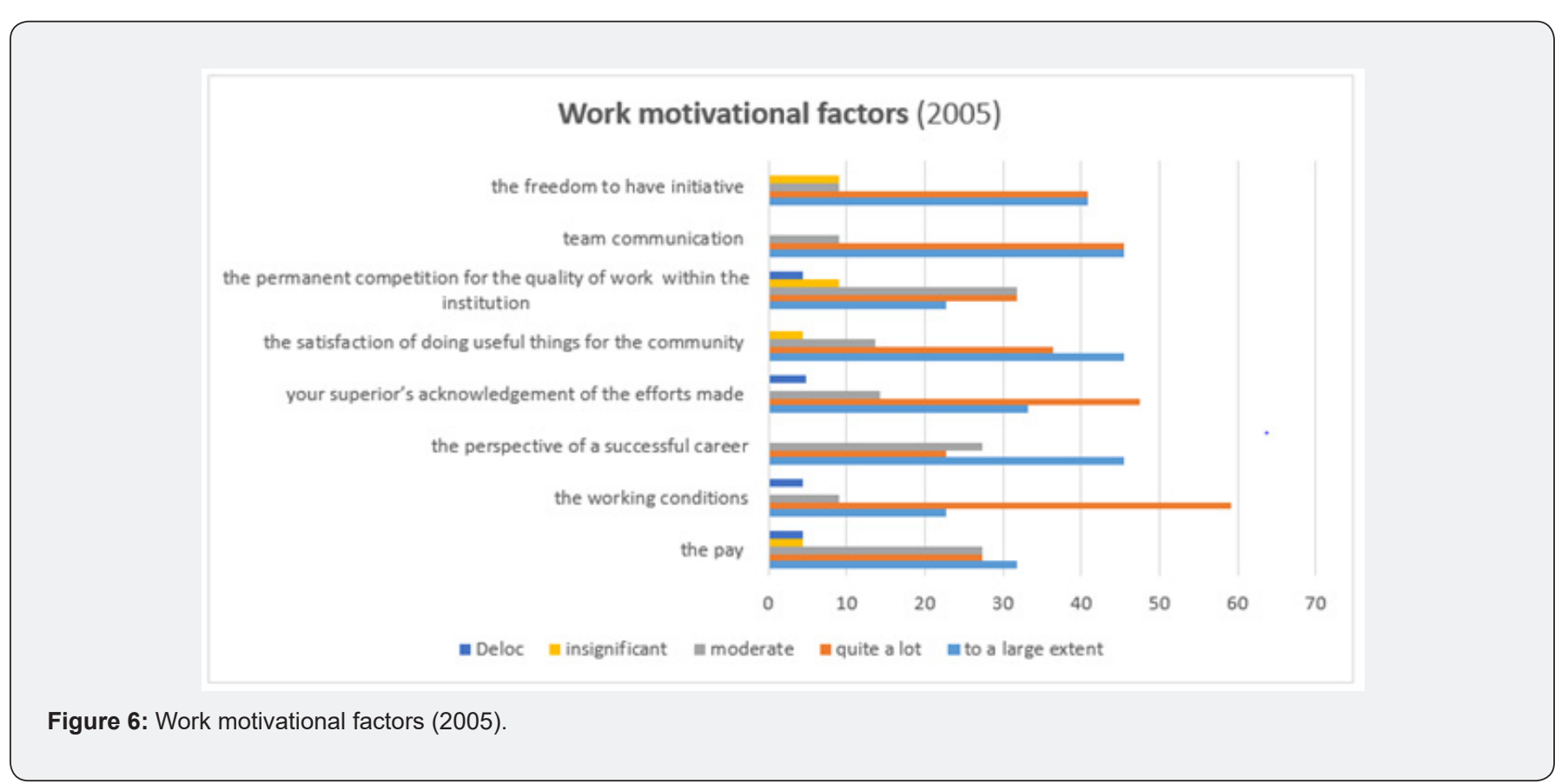

The appraisal of individual professional performance was also a subject of reform. The only criterion applied is that of the appreciation by the hierarchical superior, but both in 2005 and 2020 , a significant proportion of respondents considered that this system was not objective (Figure 8). Self-evaluation or external assessment is not used, and the results of the current assessment of individual performance are not reflected in the pay received by the civil servants. 


\section{Attendance of long and short term training courses over the past year}

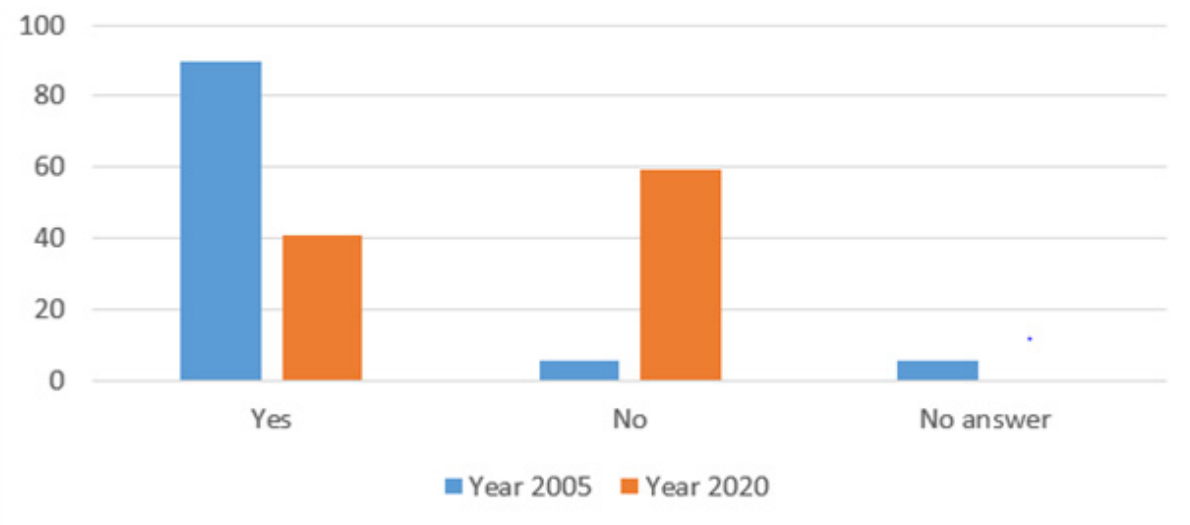

Figure 7: Attendance of long and short term training courses.

\section{Objectivity of the assessment system}

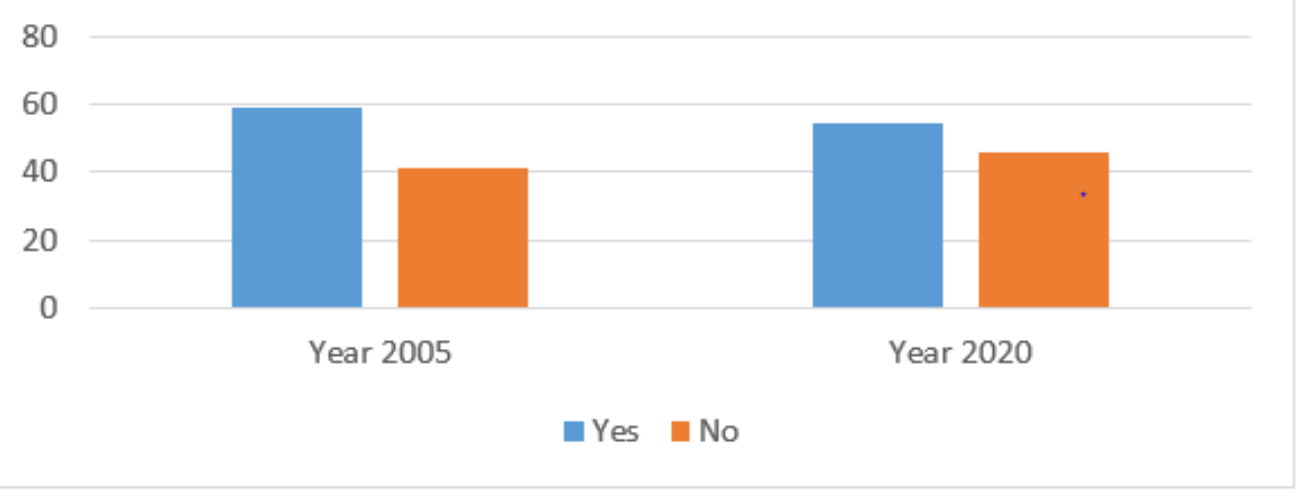

Figure 8: The objectivity of the individual performance assessment system.

The percentage of those considering corruption a problem of the public administration in Romania declined in 2020 compared to 2005 (Figure 9), which shows that the implementation of anti-corruption national strategies starting with 2012 and of the legislation on ethics and integrity has had effect (Figure 10).

While in 2005 (Figure 11) they thought that the low salaries of civil servants and the pressure of the political system were the main corruption triggers, in 2020 (Figure 10) the morality of civil servants is seen as the main source for corruption. In 2020 too, it is estimated that the political system pressure is actually generating corruption while the low pay is no longer seen as the main corruption trigger.

De-politicization and stability in the civil service are issues that have been at the center of the civil service reforms over the past 15 years. While at the beginning of the period under review (e.g. de-politicization of the prefect office) measures were implemented in this respect, the last few years have failed to bring any new in this respect. 


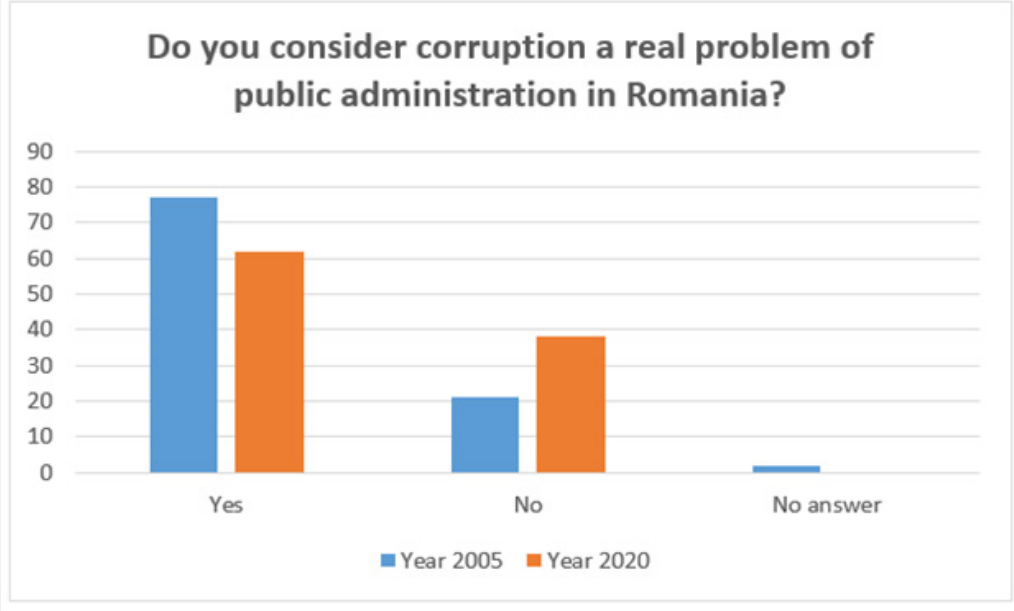

Figure 9: Corruption, a problem of public administration in Romania.

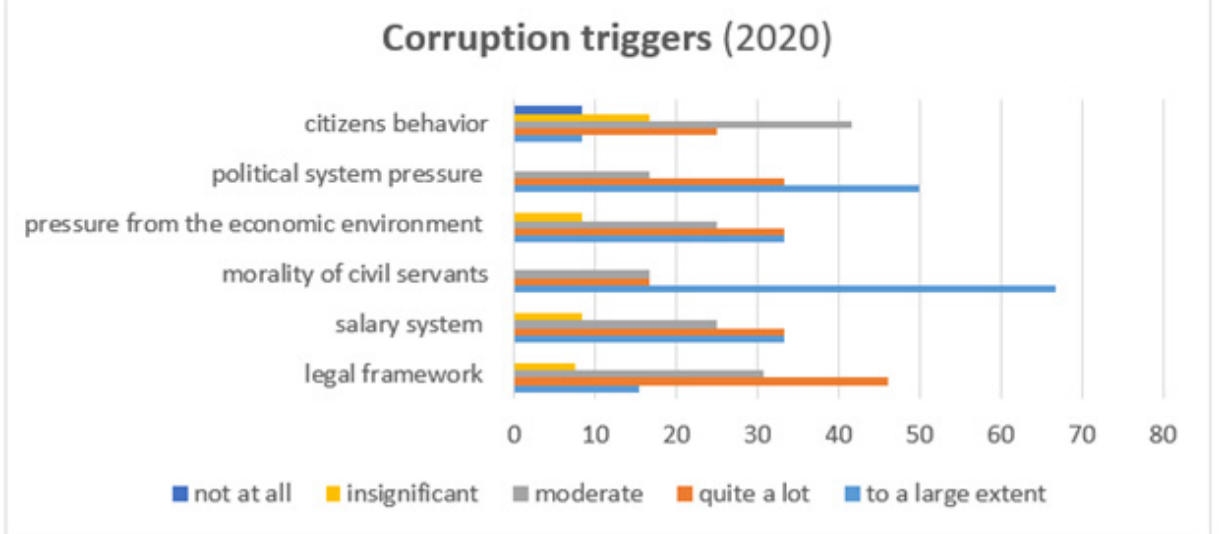

Figure 10: Corruption triggers (2020).

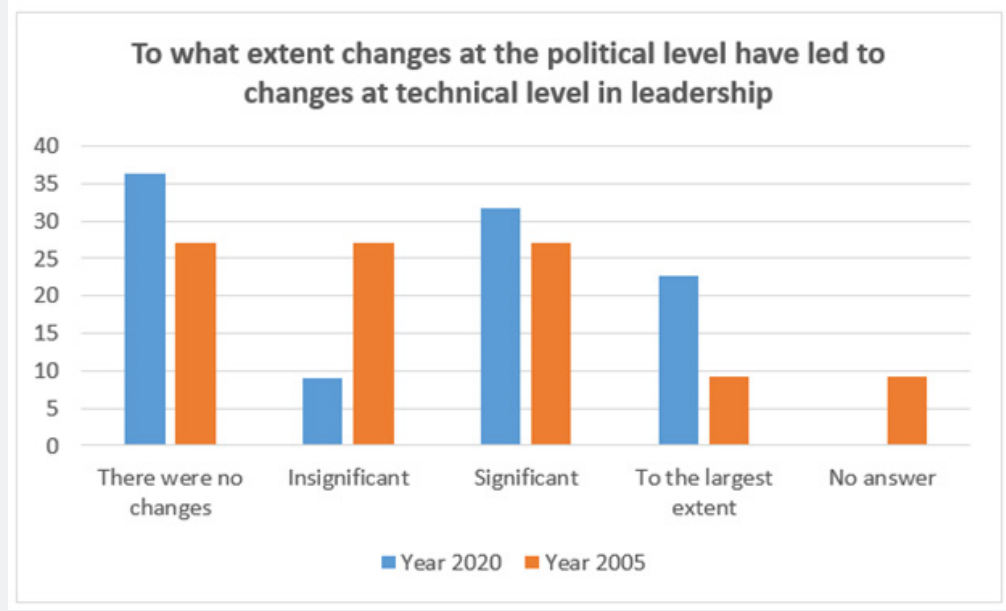

Figure 11: The extent to which political changes have led to technical changes in leadership. 
Analyzing the answers to the questionnaire, it shows that in 2020 (Figure 12) the extent to which the political changes have brought about technical changes in leadership, increased. Overall, stability in the civil service seems to be affected. However, the percentage of those who declare that if they were able to start an activity again, they would still choose to work in the public service, it is increasing, especially after the wage increases in recent years and due to compliance with labor law, compared to the private sector.

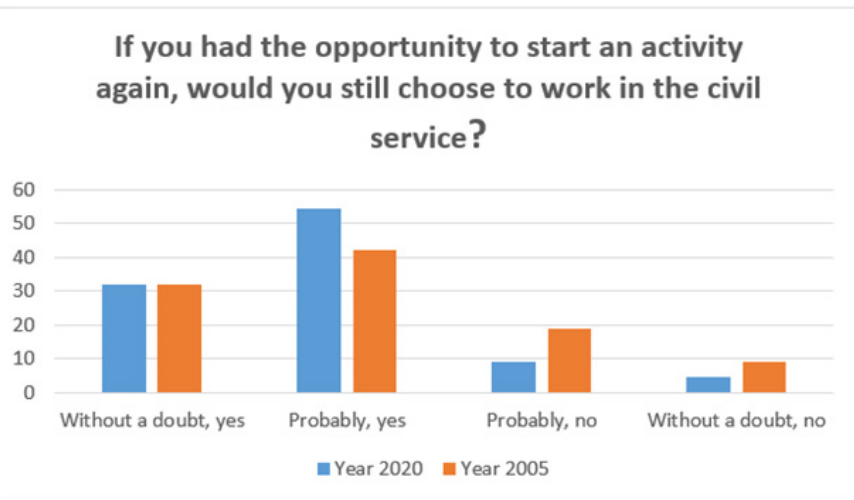

Figure 12: The comparative analysis $2005-2020$ shows that the main achievements of the civil service.

The comparative analysis 2005-2020 shows that the main achievements of the civil service reform are ethics, integrity, anticorruption measures, remuneration and working conditions. In the areas of recruitment, staff selection, training, assessment of individual professional performance, stability, career, things have not progressed but rather regressed.

\section{Conclusion}

Progress in public administration reform has been limited, although they have been a continuing concern of government members and have been the subject of reform processes over the past 15 years. Analyzing the achievements in this field, we find that the reforms were more declarative than factual.

The objectives and measures provided in the SSPA or the 20162020 Public Policy Strategy meet the needs of the civil service and are appropriate for the reform process but are not implemented.

An appropriate coordination of the process has been missing, as evidenced by the SSPA evaluation reports, according to which the National Coordination Committee for the Implementation of the Strategy for Strengthening Public Administration 2014-2020 operated sporadically without clear procedures.

Until 2014, there was not even a national coordinator of reforms in the field of civil service. Regretfully, many of the recommendations phrased 15 years ago are still topical. Further efforts are needed to put into practice the reform ideas.

The quasi-generational image of recruitment and selection of civil servants is that the fairness and objectivity of these processes is not fully assured and the staff involved are not specialized to identify those candidates who are truly prepared to meet the rigors of working in public institutions.

It is necessary to ensure the objectivity, neutrality and transparency of the recruitment and selection processes by increasing transparency, externalizing the selection process by forming a national body of professional assessors, organizing competitions once a year for the whole system (the model used in magistracy) and ensuring the functionality of the reserve body, organizing competitions based on the motivation, innovation and creativity of competitors.

Although the legislation ensures the stability of the civil service and a foreseeable career path, the many changes in the administrative system and politicization have triggered the lack of a personal career pursuit and even instability.

Lack of, or inappropriate provision of information, financial and material resources, proper working spaces, have negative repercussions on theperformance and effectiveness of civil servants work. Career enhancing measures should include elements such as the provision of information resources and primary materials for the exercise of the function, ensuring the functionality of the integrated IT system of career management, limiting temporary exercise of management functions, strengthening social dialogue in public institutions, operationalizing the parity commissions.

Political changes, irrespective of legal safeguards, have triggered many changes among civil servants, particularly for occupants of public management positions, which affect the stability of the administrative system. In terms of de-politicization, performance and morality based criteria for promotion in public positions, in full compliance with the law, the reform of performance assessment correlated with the salary granted is required. 
Despite the progress registered in terms of ethics and integrity, anti-corruption education campaigns for civil servants, dignitaries and citizens are still needed, as well as the monitoring of the disciplinary sanctions of civil servants, the elaboration of anticorruption strategies for each public institution and the monitoring of their implementation, the operationalization of the ethical counseling activity in public institutions, the general implementation of the internal/managerial control system at the level of each public institution, risks identification and mitigation, risk plans and registers elaboration for each component of the organizational structure in the public entities are further required.

In terms of professional training improvement, the current legal framework leaves it to the public institutions managers to decide the extent to which the relevant rules are applied. Despite being a civil servant's right and duty, there are many cases where employees do not have access to vocational training, as opposed to some who overindulge in this right.

The training resources are not properly used because there is no coherent system and expertise to accurately identify the needs of each public institution, there is no follow up assessment of the results obtained from the participation in the improvement/ training programs (impact analysis) and there is a limited use of alternative solutions (e-learning training system) that would reduce the costs of training and would facilitate the access thereto for many more civil servants.

In terms of improving professional training, the following is required:

-the responsibilities of the various institutional actors (National Agency of Civil Servants, National Institute of Administration, National Qualifications Agency) need to be clearly defined;

- individual and institutional training needs analyses on a multi-annual basis have to be conducted;

- the institutional mechanism linked to implementation, monitoring and evaluation of the process of continuous training has to be developed;

- cost grids for training courses need to be prepared;

- developing occupational and competence standards and correlate the training courses to them;
- the operationalization of the National Institute of Administration.

Although unitary pay has been legislated, it is not yet correlated with the assessment system. Pay is not performance granted but based on the position held in the institutional hierarchy.

It is required to correlate the appraisal/assessment system with the remuneration system. Performance appraisal is currently a formal process, at the discretion of senior civil servants. Institutional assessments are non-existent.

In terms of performance assessment, elements such as the generalization of managerial programs for all heads of public institutions, the development of the objectives setting capacity both at individual and unit level, the introduction of the external evaluation component and the selection of assessors for the deployment of external evaluation activities can be envisaged. Balanced Scorecard (BSC) is a tool that can be used.

All these measures aim at rebuilding the trust in the body of professionals in public institutions, capable of meeting the requirements of a performing public administration, as a prerequisite for good governance. The stake of this process is of exceptional importance and transcends the immediate reality - the satisfaction of the public interest through quality public service provision.

\section{References}

1. Profiroiu M, Andrei T, Dincă D, Carp R (2006) Impact studies III, Public Administration Reform in the Context of European Integration European Institute of Romania.

2. The Strategy for Strengthening Public Administration 2014-2020 (SSPA), approved by Government Decision no. 909/2014.

3. Impact assessment of the measures implemented under SSPA 20142020 - Pillar III - Human Resources, coordinator Dragoș Dincă, within the project Improving the capacity of CNCISCAP to coordinate the implementation of the Strategy for Strengthening the Public Administration 2014-2020, Code: SIPOCA 24, Beneficiary: General Secretariat of The Government.

4. Strategy for the development of the civil service 2016-2020.

5. The Strategy on the professional training in in public administration 2016 - 2020, approved by Government Decision no. 620 of 2016.

6. Activity Report of the National Agency of Civil Servants for 2018 . 
(C) Commons Attribution 4.0 License BY DOI: 10.19080/ASM.2021.06.555690
Your next submission with Juniper Publishers will reach you the below assets

- Quality Editorial service

- Swift Peer Review

- Reprints availability

- E-prints Service

- Manuscript Podcast for convenient understanding

- Global attainment for your research

- Manuscript accessibility in different formats

( Pdf, E-pub, Full Text, Audio)

- Unceasing customer service

Track the below URL for one-step submission https://juniperpublishers.com/online-submission.php 